\title{
Dissemination of Environmental Information and its Effects on Stakeholders' Decision-Making: A Comparative Study between Swedish and Polish Municipalities
}

Anna Cregård, Iwona Sobis

\begin{abstract}
According to Action Agenda 21, which was adopted at the Rio Conference in 1992, sustainable development is a major objective for local and global development. Economic growth, good living conditions, and protection of the earth's natural environment are important to all people in the world. This article focuses on one aspect of sustainable development, i.e. on environmental sustainability. Research shows that local government can take a leading position in protecting the natural environment and disseminating information on it among stakeholders. However, our knowledge about the dissemination of environmental information practices among stakeholders is limited.
\end{abstract}

The purpose of this research is to fill a gap in current knowledge, to describe and compare the practical work with dissemination of such information among stakeholders in Swedish and Polish municipalities. The questions to be answered are: What environmental information is collected and produced by the local government? At what stakeholders is such information targeted? and What effects does it have on decision-making by stakeholders in the investigated municipalities? The study is based on state regulations, the homepages of municipal offices, and policy documents, official reports, and semi-structured interviews with key managers responsible for the protection of the natural environment in the studied municipalities. Data were collected from late 2015 to early 2017.

This research indicates that dissemination of environmental information has a positive effect on the decision-making of internal stakeholders. In both countries, the municipal authorities follow the EU recommendations, resulting in innovative work and growing environmental awareness among the municipal authorities, the 
residents, and other stakeholders. Improvement of the natural environment is perceived as "a must" for the future. Nonetheless, especially larger municipalities face challenges because the production and dissemination of environmental information is time-consuming. In the long run, however, surprisingly positive effects on the local protection of the natural environment appear.

\section{Keywords:}

Sustainable development, Action Agenda 21, environmental sustainability, environmental information, practical work, dissemination.

\section{Introduction}

The European Union (EU) has supported the "Declaration on Sustainable Development" since it was first proclaimed at the 1992 United Nations Earth Summit in Rio de Janeiro, and all member states of the EU have committed themselves to adopting sustainable development strategies. In 1997, the Amsterdam Treaty, which in Articles 2, 3, and 6 introduced sustainable development as a core objective of the EU, was also signed. Four years later, in 2001, "the European Union adopted its Sustainable Development Strategy in Gothenburg, and in 2002 the external dimension of the Strategy was added by the European Council in Barcelona and the European Union was active in supporting the conclusions of the World Summit on Sustainable Development in Johannesburg" (Communication from the Commission 2005, 218 final). Realising Action Agenda 21 on sustainable development has become the major objective of local and global development because the combination of economic growth, good living conditions, and protection of the earth's natural environment are deemed to be of crucial importance to all people in the world. Attempts to realise this objective have resulted in a growing number of regulations, directives, and recommendations, which demands the spread of standards and best practices to influence capacity-building processes at all governance levels across Europe and the neighbouring countries and contributes to administrative convergence. Some scholars (Olsen 2003; Trondal and Jeppesen 2006; Hofmann 2008: Heidbreder 2011; Trondal and Peters 2013; Sobis and de Vries 2017) described this phenomenon as the rise of the European Administrative Space (EAS). However, there are local governments and public-sector agencies that are expected to lead efforts for sustainable development and to spread information about the results of such efforts (Ball et al. 2006; Marcuccio and Steccolini 2005; Ball and Osborne 2011). If they do so, they show accountability and retain their legitimacy, but they cannot accomplish this on their own. These public-sector authorities have to cooperate with other organisations and various stakeholders (Farneti and Guthrie 2009; Adolfsson Jörby 2002; Feichtinger and Pregernig 2005). Also, local governments can potentially learn a lot from each other's experiences, and this requires dissemination of their experiences and results. 
Nonetheless, as scholars have argued (e.g. Deegan et al. 2002; Wilmhurst and Frost 2000; Steccolini 2004; Larrinaga-Gonzalez and Perez-Chamorro 2008), we do not know much about the dissemination and use of such information and experiences. According to these authors, most research focuses on the content of annual reports, brochures, or other documents on sustainability, which are easy to obtain, while investigations on the dissemination of information about sustainability and the practical use of such information by local authorities or other stakeholders when making decisions is still limited. In order to fill this knowledge gap, we focus only on one aspect of sustainable development that concerns the protection of natural environment. The purpose of this article is to fill a small gap in current knowledge, to describe and compare the local governments' practical work with dissemination of environmental information among stakeholders. The work presented here focused on municipalities in Sweden and Poland and sought to answer the following questions: (1) What environmental information is collected and produced by the local government?; (2) At what stakeholders is the environmental information targeted?; (3) What impact does such information have on stakeholders' decision making?

In this article, environmental information is understood as everything that has to do with the rates of renewable resource harvest, pollution creation, and nonrenewable resource depletion that can be continued indefinitely. If they cannot be continued indefinitely, then they are not sustainable. This includes climate, stability, air, land and water quality, land use and soil erosion, biodiversity (diversity of species and habitats), and ecosystem services (e.g. pollination and photosynthesis). Dissemination of such information means that the information may be created, produced, collected, prepared, forwarded and/or presented by a local government in a manner that makes it available to any stakeholder. Regarding the concept of stakeholder, we follow Freeman's (1984) definition according to which stakeholder is understood as "any group or individual who can affect or is affected by the achievement of the organizations' objectives" (46). The impact of environmental information on decision-making by stakeholders is understood in a colloquial way, i.e. how the respondents understand and express it. Making use of information in desicion-making is considered to have a broad meaning in this article and includes all steps of the decision process (see, e.g., Mintzberg, et al. 1976); identifying, recognising and diagnosing a problem or opportunity; searching for and developing alternatives; and selecting alternatives and acting accordingly. It is important to note, however, that it is the municipal respondents' experiences and perceptions of stakeholders' use of the information that is investigated.

The comparison between the Swedish and the Polish municipalities is chosen because both countries have a long tradition of mutual cooperation, which has increased during the Polish transition from socialism to a market economy, starting in 1989. Sweden was one of many Western countries that provided assistance in preparing Poland to access the EU (Sobis 2002; Sobis and de Vries 2009). This cooperation between the countries is still visible in many respects. Since 1995 and 
2004 respectively, Sweden and Poland have been member states of the EU, and they have to follow the EU recommendations dealing with sustainable development in a similar way as is obligatory for the other EU's member countries. However, how the countries do this in practice can vary.

This paper is structured as follows. After this introduction, the theoretical approach is presented in section 2 . The method of investigation is described in section 3. In section 4 , we present the findings on the dissemination of environmental information practices and the use of such information by stakeholders when making decisions. Finally, in section 5 we answer the research questions, discuss the results, and draw conclusions.

\section{Recent research on local governments' practical work with sustainability information}

From an idealistic point of view, one would expect municipalities to take action promoting sustainable development by creating relevant policies, reporting on practical sustainable work and its results, disseminating such information among stakeholders to create a foundation for farther discussions with stakeholders about the consequences of such policies. The aim would be to improve them. Adams and Larrinaga-Gonzalez (2007) support such positive expectations of transparency in reporting about improved sustainability practices in organisations and maintain that research on environmental accounting and reporting ignores practical work within organisations. Thus, they advocate more research in this regard "to improve theorizing, practice and the sustainability performance of organizations" (332) but also to explain factors behind improved environmental sustainability and managers' accountability. Moreover, they share the opinion that the improvement of managerial sustainability work can also improve making decisions about future local development. However, Adams and Larrinaga-Gonzalez emphasise that "managerial capture" should always be investigated in its local context.

Williams, Wilmshurst, and Clift (2011) investigated sustainability reporting within the Australian local government context: to what extent the local authorities were reporting on sustainability. The research was based on a mail survey and concerned environmental protection, economic growth and social equity. The authors asked four questions: "Do local government authorities in Australia report on sustainability? What reporting media are used to report this information? What is the reporting focus of sustainability reporting? What are the future plans for sustainability reporting in local government?" (177). They came to the conclusion that local government was of decisive importance for the implementation and facilitation of sustainable practices in general and, hence, the protection of the natural environment, too. According to them sustainability reporting in Australia showed 
a growing tendency and a great potential for utilising sustainability reporting for sustainable development and its planning.

Feichtinger and Pregernig (2005) compared the Local Agenda 21 processes in Helsingborg (Sweden) and Vienna (Austria). They investigated the role of the European Initiative Local Agenda 21 and the International Council for Local Environmental Initiatives at the local level looking for the varying implementation approaches of common international political commitments. They found that cross-border networks for the development of sustainability programmes were being created. Thus, the institutions described in their report provided opportunities for citizens to participate in Local Agenda 21, at least in those areas that were especially important to the local context. The study showed that this ideal picture did not always reflect what really were going on at the municipal level, and national differences were seen; e.g. when comparing Sweden and Austria, Feichtinger and Pregernig (2005) found that the Swedish municipalities' work was driven much more by experts and technocrats than by citizens' participation, as was more the case in Austria.

Several factors appeared in the literature that could explain such different approaches; e.g. Ball (2005) investigated "how a UK local government council was responding to an environmental agenda in the context of an array of gradual political, functional and social pressures to change its activities" (346). Ball applied the Oliver model of change/appropriation (1992), combined with Larrinaga-Gonzalez and Bebbington's theory (2001) dealing with the array of political, functional and social pressures. They made distinctions between macro-level appropriation, micro-level appropriation and mechanisms for achieving appropriation $(2005,348)$ but they also paid attention to internal and external pressures (350). This study provided some "insights into the positive and negative pressures" leading into a better understanding of institutional change at the British county council. However, this study did not explain which kinds of pressure had real impact on the positive changes. Other studies, conducted by Ball (2005) and Ball and Bebbington (2008), pointed to the crucial role of local governments; they had direct contact with various stakeholders in the organisational environment, and that had a significant impact on other organisations' performance and on people's daily lives. Bellringer et al. (2011) studied the reasons behind sustainability reporting by the local governments within the New Zeeland context. This study was based on semi-structured interviews with the person responsible for preparing the sustainability report. The authors had partly replicated the Farneti and Guthrie study (2009), addressing experiences of local governments: how sustainability reporting was carried out, including reference to any guidelines; how information was collected and reported; and who was involved. They concluded that managers of local governments were more concerned with self-serving legitimation and pretending to be accountable than with any genuine concern for the sustainable development. Greco et al. (2015) highlighted the political negotiations in which sustainability reporting was only included because it 
was seen as a "must" for organisations. Wilmhurst and Frost (2000), Deegan et al. (2002), and Steccolini (2004) argued that the dissemination of information through reporting was directed primarily to external stakeholders. Lodhia et al. (2012) analysed the environmental reporting practices within public-sector entities in 19 Australian Commonwealth Departments. The reports were analysed in line with a content-analysis instrument based on the Global Reporting Initiative (GRI), which was perceived as the international standard. The authors came to the conclusion that national legislation, internal policy or internal drivers' requirements had more influence on the dissemination of sustainable information than the GRI.

Some scholars, e.g. Ball and Osborne (2011), pointed to the crucial role of stakeholders themselves. According to Freeman (1984), stakeholders are defined as "any group or individual who can affect or is affected by the achievement of the organizations' objectives" (46). Nonetheless, stakeholders can be perceived in different ways. There are internal and external stakeholders, and countries vary in the extent to which the internal or the external stakeholders are the more important ones. Farneti and Guthrie (2009), who have been quoted before, assert that the most important ones among the multitude of local stakeholders are the public sector's internal stakeholders. Their research suggests that the public sector has predominantly an inside-out perspective on daily work with sustainable development and the dissemination of such information (see also Burritt and Schaltegger 2010). In Sweden, Adolfsson Jörby (2002) investigated the practical work with Local Agenda 21 in four Swedish municipalities. She focused on "ethical, social and environmental (or sustainability) accounting and accountability, which engages with those organisations claiming to manage and report their sustainability performance" (333). Adolfsson Jörby found more balance between internal and external stakeholders along with increasing internal and external collaboration with stakeholders. Moreover, the author is of the opinion that such research has "the potential to improve theorizing, practice and the sustainability performance of organizations" (333, see also 339 and 349).

Manetti (2011) studied 174 sustainability reports in English, Spanish, and Portuguese that were written in line with the Global Reporting Initiative and which presented the best practices of corporate citizenship. The aim of that work was to investigate the quality of stakeholders' engagement in sustainability reporting, and Manetti found that most companies had much more interest in stakeholders' management than in their engagement in sustainable development. However, stakeholders also vary in the extent to which they are active or passive. For the case of Australia, Farneti and Guthrie (2009) conclude that sustainability information is produced because stakeholders organise themselves in an active way to enhance sustainable development. They want to be seen as serious actors in a similar way as managers of local governments. Rixon (2010) investigated the importance of stakeholder participation in the local governments' strategic planning processes, and she asked the question "if the various consultative forums employed are effective in increasing ac- 
countability or are meetings held with stakeholder groups just to say they have been consulted?" (347). Rixon referenced Friedman and Miles (2006), who proposed an interesting classification of stakeholders' participation in decision-making that consists of three levels: (1) the lower level representing the autocratic management style dealing with manipulation, therapy and informing; (2) the middle level giving the powerless a voice, with a two-way dialogue based on specially chosen stakeholders representing their groups, stakeholders have some power to influence local development; and (3) the high level of engagement, empowering stakeholders in corporate decision-making. Rixon is of the opinion that if public-sector organisations want to be perceived as accountable for local development, the consultations with various groups of stakeholders should go far beyond the dissemination of environmental information, stakeholders' participation in surveys, and round tables discussions organised by local authorities. She argues that the Canadian stakeholders participate in "true consultations" (355); thus, she draws the conclusion that the engagement of stakeholders can be used by local government in strategic planning, which ensures the local authorities' accountability towards the local community. Another study discussing stakeholders' engagement and the benefits of dialogue and communication is that of Wibeck et al. (2006), which focuses on management by objectives (MBO) in public environmental management. The aim of this study was to identify and discuss obstacles in communication, when using $\mathrm{MBO}$ in public environmental management (462). Using the dyadic and focus-group interviews with civil servants at various levels of the Swedish environmental administration, as well as official reports on the national communicative strategy for achieving environmental objectives, the authors studied the implementation, administration, and assessment of Swedish environmental quality objectives. This study reveals that real engagement is visible in a dialogue clarifying the differences in understanding the major objectives for local sustainable development. Such a dialogue can make those involved more aware of sustainable development and its consequences, and it can help to find good indicators for measuring progress or for identifying goal conflicts. Thus, the dialogue can essentially contribute to minimising or even eliminating the negative effects of development on the natural environment.

Last but not least, the dissemination of environmental information is a matter of priorities. Larrinaga-Gonzalez and Perez-Chamorro (2008) studied how Spanish public water companies communicated such information to their stakeholders, and they explored whether more progressive accountability was visible in the public sector in comparison to the private sector. Their research was based on documents, annual reports, and accounts from the period 1997-2005. They found that although it was mandatory for public organisations to share environmental information with their stakeholders, public organisations were engaged formally as well as informally in reporting the outcomes of sustainability work, and that reporting was connected to organisational strategies and operational activities; in practice the dissemination 
of such information was rather meagre. They explained this finding by pointing to the other priorities that Spanish water companies had to focus on.

Burritt et al. (2009) conclude that what local governments are doing in terms of reporting on sustainability is an area deserving further research. Gray et al. (2009) and Guthrie et al. (2010) assert, too, that research on the dissemination of sustainability information by local governments is rather limited. The studies that do exist mostly focus on one country at a time and use single case studies based on survey techniques. Therefore, this study aims at filling a small gap in our knowledge about the dissemination of environmental information among stakeholders and its effect on decision-making by stakeholders. The next section will describe how this study was conducted.

\section{Method}

\subsection{Selection of municipalities}

The empirical investigation is designed as a descriptive and comparative case study, focusing on Sweden and Poland as the cases. Both countries are member states of the EU, and as such they have to follow similar directives in line with Action Agenda 21. When selecting the Swedish and Polish municipalities, we were looking for as much comparability as possible - despite the fact that Sweden and Poland have different histories, sizes, understandings of democracy, legislations, administrative divisions, etc. Finding equivalents was not possible, instead we had to find another way of finding comparability. Therefore the selection process covered three steps. In the first step we selected a region within the respective country that would serve well for comparisons. The reason for starting with the selection of regions is that the municipalities within a region can be expected to cooperate in fundamental issues, such as sustainable development. In addition, it is not uncommon for the larger city within a region to take great responsibility and leadership in such matters. Regions as a basis for the selection process should therefore prevent us from misunderstanding the respective municipality's relation to each other. The choice of one region in Sweden and one in Poland was based on the fact that they should 1) have a similar socio-economic structure; 2) be of approximately the same size; and 3) be facing the same sustainability challenges. The second step in the selection process included selecting the larger city within each region and three other municipalities situated in direct contact with the city that could serve for comparison. In the third step access to the municipalities was ensured.

The selected regions were the Västra Götaland Region (VGR), which represents the self-governing authorities in Sweden, and the Łódz Voivodship (ŁV), which represents the state administration in Poland. The administrative divisions of the countries differ, but the delegation of power to the local level is similar. In this article, the VGR from Sweden and the EV from Poland are perceived as two com- 
parable cases. The cases have a similar socio-economic structure, a challenging industry that generates more pollutions than in other parts of the countries, a similar size of the municipalities and the number of citizens in each studied municipality. Secondly, the selection included the biggest city of, respectively, the region and the voivodship and three smaller municipalities situated in the close proximity of the big city. It should be added that the selected municipalities in both countries have a relatively good reputation in terms of protecting the natural environment.

\subsection{Presentation of investigated cases}

The Kingdom of Sweden belongs to the Scandinavian countries in Northern Europe. It is the third largest country in the EU by area at 450,295 square kilometres and with a total population of approximately 10 million people as of November 2016. The country has a low population density of 21 inhabitants per square kilometre, and the highest concentration of population is in the South. The total GDP (PPP) is about $\$ 498,130$ billion and $\$ 49,698$ per capita (SCB 2016).

In Sweden, the public sector is organised on three levels - the national level (state authorities), the regional level (county councils), and the local level (municipalities). Since 1995 there is also a fourth level, the European level, which is becoming increasingly important. The local level is by far the largest one, both when comparing expenditures and the number of employees (SCB 2016). There are 290 well-established and independent municipalities at the local level. The municipalities vary in size, with the smallest having approximately 2,500 inhabitants and the largest more than 810,000 inhabitants (on average the municipalities have 32,000 inhabitants and about 2,500 employees). The municipal sector is characterised by a strong self-government, which means that a municipal council is an autonomous authority in decision-making in areas such as social services, roads, water, schools, preschools, elder care, and, of course, environmental issues. The Swedish Local Government Act regulates municipal activities, which are financed by local taxes, government grants, and fees. The Swedish Constitution mandates the municipalities' right of taxation.

The Västra Götaland Region was created in 1998 by merging the county councils of Gothenburg, Bohus, Älvsborg, and Skaraborg. The highest governing body is the regional council, whose members and alternates are elected in general elections. The regional board is elected by the regional council and has executive political responsibility. The regional board prepares matters discussed in the council. The regional council is responsible for the regional development and particularly for the public healthcare system and public transport. The Västra Götaland Region consists of 49 municipalities. It has an area of $25,247 \mathrm{~km}^{2}$ and a population of $1,615,000$ residents according to data from 31 December 2013.

The Västra Götaland Region accounts for $20 \%$ of all Swedish carbon emissions. The total emissions were 12.5 million tonnes in 2008 , which is the equivalent 
of about 8 tonnes per capita. The corresponding values in Stockholm and Skåne were around 3 and 5 tonnes, respectively. Half of the emissions in the Västra Götaland Region (more than Stockholm's total emission) come from the energy required by heavy industry, such as refineries. Emissions in the transport sector are slightly higher than in Skåne and significantly higher (by almost a tonne per person per year) than in Stockholm. Greenhouse gas emissions decreased by approximately $2 \%$ between the years 1990 and 2008 (Algehed and Eriksson 2012, 8). The Västra Götaland Region's total greenhouse gas emissions (converted to carbon dioxide) were 11.2 million tonnes in 2012. Between 1990 and 2012, total emissions fell by $10 \%$, while during the same period gas emissions in Sweden decreased by $21 \%$. The reason for why gas emissions in the Västra Götaland Region were not reduced to the same extent as in Sweden as a whole can be explained by the presence of refineries in the region that have increased their production compared to 1990 and have thus increased their share of the total emissions in the region. The largest reduction in emissions in the region has occurred in energy supply as a result of the transition from oil heating to district heating. Moreover, emissions from industry, energy supply, and waste management have decreased, but emissions from road transport and construction are still considered too high (Fakta Västra Götaland 2015).

The Republic of Poland is situated in Central Europe. Its total area is 312,679 square kilometres, and it is the $9^{\text {th }}$ largest country in Europe with a population of over 38.5 million people. Poland has a high population density of 123 inhabitants per square kilometre, and thus the Polish population density is about 6 times higher than in Sweden. The Total GDP (PPP) is about $\$ 1.051$ trillion and \$27,654 per capita (GUS 2016).

Since 1 January 1999, the Polish system of public administration has been divided into two major administrative bodies. The first is the governmental administration at the state-administration level and at the voivodship level, and this level includes the state agencies relevant for sustainable-development issues, including the Material Reserves Agency, the Polish Agency for Enterprise Development, and since 2009, the Agency for Restructuring and Modernisation of Agriculture and the auxiliary entities of state administration with regional units. The second level is the local-government administration, which has a three-tier structure: (a) municipal government ("gmina" and cities with "powiat" status), (b) powiat government, and (c) voivodship government. The Polish government system is not hierarchical, which means that the voivodship authorities cannot impose anything on the powiat or the municipality. Each local government acts independently, within its competence, and carries out the tasks entrusted to it. The basic unit of local government is the municipality. Each municipality carries its own responsibilities, which meet the needs of inhabitants with regard to: (1) technical infrastructure (maintenance of municipal roads, water supply, sewerage) and social infrastructure (organisation of municipal health care-facilities, social welfare, nurseries, primary and lower secondary schools); (2) public order and security (fire protection, sanitary safety, pub- 
lic security can be set up to safeguard public order); and (3) spatial and ecological order (creation of the spatial development plan of the municipality, management of the property owned by the municipality, communal, protection of the natural environment). Since 2004, Poland has been a EU member state, so we can also talk about the European level that provides the national government, but also the local administration, with regulations and recommendations. In Poland, the Local Government Act and the national constitution regulate municipal activities, which are financed by local taxes, government grants, and fees. The Polish Constitution mandates the municipalities' right of taxation.

In Poland, as of 31 December 2015, there are 16 voivodships, 314 powiats, and 2,478 municipalities, of which 306 are city municipalities, 602 are town-rural municipalities, and 1,570 are rural municipalities (GUS 2016, 139). In terms of population, the largest city municipality is Warsaw (1.7 million inhabitants) and the smallest is Krynica Morska with only 1,400 inhabitants. The most populated rural municipality is Chelmiec with 24,738 inhabitants, and the smallest rural municipality is Cisna with 1,676 inhabitants (Dziennink: Warto Wiedziec 2011).

The Łódz Voivodship is one of the smallest in Poland, and it consists of 117 municipalities and 24 powiats, of which 3 powiats possess city rights. In 2014, its area was $18,219 \mathrm{~km}^{2}$ and 2,504,100 people were living there.

In the Łódz Voivodship, the emissions of particulates and gases with a negative effect on air quality improved between the years 2005 and 2014. In 2005, the emission of particulates was 7,900 thousand tonnes, while in 2014 it was 2,800 tonnes per year. In 2005, the emission of gases was 37,526 tonnes, while in 2014 it was 41,846 tonnes per year. In $2005,3,733$ tonnes of particulates were retained in pollutant reduction systems, and in 2014 this had increased to 4,960 tonnes. General waste, excluding municipal waste, was 9,937 tonnes, and municipal waste was 642,100 tonnes (Ochrona Srodowiska w Wojewodztwie Łódzkim 2014, 79; Rocznik Statystyczny Województwa Łódzkiego 2015, 30, 69).

\subsection{The data collected and key respondents}

This study is based on: (1) EU, national, regional/voivodship, and local regulations on sustainable development, focusing particularly on the protection of the natural environment, (2) secondary data from the national and regional/voivodship statistics in both countries, (3) local policy documents and the homepages of the investigated municipal offices and regional/voivodship agencies responsible for the protection of the natural environment in both countries, and (4) semi-structured interviews conducted with key managers of the selected municipal governments who were responsible for environmental issues and the dissemination of environmental information. Data were collected from late 2015 to early 2017.

The questions addressed in the interview guide related to the research questions: (1) What environmental information is collected and produced by local 
government and why?; (2) To what stakeholders is the environmental information targeted?; (3) What impact does such information have on stakeholders' decisionmaking? For each theme, we asked follow-up questions in order to gather in-depth information.

We interviewed the respondents via face-to-face contacts and by telephone. On average, the interviews lasted for about one hour. The interviews were held in the native language of the participants, which ensured a better understanding between the interviewer and the respondents. The interviews were recorded, but we also took extensive notes. We transcribed the interviews verbatim, and the most relevant parts of the interviews or illustrative quotes were used as evidence of the respondents' opinions or experiences. The inclusion of two interviewing researchers, the different techniques for conducting the interviews, the translation of the interview guide from Swedish into Polish, and writing the whole article in English might have influenced the findings. However, we have handled the risk of misinterpretations by re-listening to the recordings; re-reading the transcripts, notes, and other written empirical material; and returning to the key respondents when needed.

Regarding ethics, when studying public-sector organisations, it is very difficult to protect the anonymity of the respondents. The municipal offices in both countries have their own homepages on which everyone can find information about politicians, heads, managers, how to contact them, on-going activities, published reports, etc. It is a question about the transparency of the public sector. The respondents from the Swedish smaller municipalities have asked for anonymous participation in this research, so we have done the same for the Polish respondents (the present presentation of findings has been agreed upon). Thus, when referring to a respondent's statement, we use the following information: Interview 1 from the Västra Götaland Region (Interview1, the VGR), for Interview 1 from the Łódz Voivodship (Interview 1 , the $€ V$ ), etc.

\section{Findings}

The presentation of research findings is structured according to the research subquestions and divided between the two cases. The comparisons between the Swedish and the Polish cases sum up each sub-section.

\subsection{Collection and production of environmental information by the Swedish and Polish municipalities}

\section{The municipalities from the Västra Götaland Region}

Local government has a long tradition in Sweden, but we did not find any state regulations that demanded mandatory reports on sustainability from a Swedish local government up until 2013. The situation changed in 2014, and ever since the Swed- 
ish local governments have to report their energy consumption and environmental protection costs to Statistics Sweden (SCB - Statistiska Centralbyrån). Other mandatory reports concern the environmental impacts of urban and rural planning.

According to the key respondents from the municipal governments of the Västra Götaland Region, the municipal authorities collect and produce a fair number of reports concerning environmental sustainability issues. These include annual reports and environmental risk analyses such as the Annual Report on Sustainable Transport, Sustainability Strategy Investigation 2050, the Action Plan for Sustainable Energy (within the Covenant of Mayors), the Environmental Footprint Report, the Environmental Sustainability Strategy Report 2010-2016, and the Climate Plan and project reports on specific environmental topics as well as reports on decontamination work and separate annual energy reports. Particularly the large municipality collects and produces an extensive amount of environmental information, even on a daily basis, for example, in terms of nitric oxide, nitrogen oxide, sulphur oxide and ground-level ozone in the air. The large municipality also has extensive information on the sea and coastal environment, forest and land, and about energy use, waste management and environmental contaminants. But also the smaller municipalities collect and produce a fair amount of information, and they differ in ambition. A typical quote from the respondents is: "We collect a lot of information and we are engaged in many, many reports" (Interview 3, the VGR).

The investigated municipalities cooperate in sustainability issues, e.g. within a network of municipalities in the Western part of Sweden. According to the respondents the large municipality is taking a lead in environmental sustainability reporting - it has the necessary resources. Also one of the smaller municipalities is aspiring to become a leader in the protection of natural environment in just a couple of years.

The annual report is the most important and extensive document according to the respondents, and the municipal governments spend considerable resources in producing them, making them accessible, and worth reading. Awards are provided for local governments that produce outstanding annual reports by, e.g., research associations such as Municipal Research in West-Sweden (Kommunforskning $i$ Västsverige) and audit organisations such as PriceWaterhouseCoopers. The annual reports include standard financial information, information on the activities of the local governments' departments, an administration report, a personnel report, and an environmental statement along with the key indicators of environmental performance such as greenhouse gas emissions, the amount of waste per person per year, and the proportion of organic food purchased by the municipal government. The section of the annual report concerning environmental sustainability activities is predominantly non-financial. There are also examples of specific environmental accounting reports that focus on water, waste (e.g. sorting heavy metals contained in soil), air quality, greenhouse gases, kilowatt-hours of electricity use per citizen, 
and the number of cars per citizen. Other reports that also provide environmental information are town-planning reports, transportation reports, and various project reports on sustainability that cover a range of topics, such as water, fair trade, and healthy food.

The production of environmental information requires data collection and feedback from various stakeholders on the reports, strategy documents, and plans for environmental sustainable development that have already been published. The respondents pointed out that Facebook pages of the investigated municipal offices, especially the parts dealing with environmental sustainability, proved to be very popular among various stakeholders. On the one hand, the website informs people about current activities and plans for the future that are connected to sustainable development. On the other hand, Facebook has become an opportunity to receive direct feedback and very interesting insights in the everyday work with environmental development as well as what is perceived as good sustainable reporting. The municipal governments have received some positive comments, e.g. on their energy plans. One of the respondents expressed it as follows:

Of course, we get a lot of 'likes', but it is from a very specific group: young, devoted to environmental sustainability work, and they have a lot of contacts. Often they sympathise with the Green Party or the Left Party, but not always, of course. However, it is not the average citizen, not the voice of everyone, not even the voice of the next generation (Interview 2, the VGR).

Thus, feedback is based rather on ad-hoc responses.

\section{The municipalities from the Eódz Voivodship}

Similarly to Sweden, the Polish municipal governments produce a lot of environmental information. The Law on Local Government, Art. 7.1, obliges the municipalities to meet the collective needs of the community and to make its activities transparent. The law concerns (1) spatial order, real-estate management, protection of the natural environment, and water management; (2) municipal roads, streets, bridges, squares, and traffic organisation; and (3) water supply, sanitation, cleaning up of waste water, cleaning up of sanitary facilities, landfills, neutralisation of municipal waste, and the supply of electricity, heat, and gas.

All of the interviewed key managers from the municipal governments within the Łódz Voivodship referred to the legislation and those matters mentioned within the Local Government Act that they perceive as having high priority. The reporting on the protection of the natural environment in the Łódz Voivodship has been seen as mandatory, and the Polish municipalities are obliged to present environmental information on the municipal offices' homepages. Everyone can download this information, but also state regulations, municipal regulations, local policies, municipal reports, announcements, notifications, proclamations, 
protocols from meetings, and protocols from social consultations. Access to such information is unlimited for the public. From the interviews, it appears that some information on environmental sustainability involves such produced documents as the Development Strategy, the Report on the State of the City, the implementation of the Integrated Strategy for Sustainable Development, 2020+, the Environmental Protection Program, the Challenges for Sustainable Development, the Waste Management Plan for the years 2009-2011, the Sustainable Development of Transport, the Environmental Program.

The strategy reports, the development programmes, the environmental protection programmes, and the annual reports for the Marshal Office - the voivodship budgetary unit without legal personality, the Voivodship Office, and the Statistical Office produced by the municipal governments in the Łódz Voivodship present a general description of each municipality, and they are related to the common development strategy of the whole Łódz Voivodship. These reports take the current state of the municipality into account within its specific socio-economic context, and they also address environmental and social problems or other main challenges, like the reconstruction and revitalisation of the historic parts of the municipalities. They also present an increasing number of local activities aimed at sustainable development so that a municipality can be competitive with other Polish and European municipalities. Some strategy reports produced by the municipal offices point out examples of good practice, i.e. the projects aimed at improving living conditions and environmental protection that have been implemented in the investigated municipalities.

The most important matters regarding the natural environment within the investigated municipalities proved to be the use of renewable energy sources, the development of infrastructure for environmental protection, and heating systems. We have identified the following key programmes within the municipalities: (1) comprehensive thermal modernisation, which can contribute to positive environmental changes as well as to large cost savings, (2) the optimisation of heat energy through the exchange or reconstruction of the main networks of energy transmission and distribution, and (3) the exchange of coal stoves for more ecologically friendly stoves providing low-emission combustion and protecting against smog, etc. All of the annual reports, development programmes, strategy reports, and environmental protection programmes from the investigated municipalities to some degree emphasise the need for improvement in the above-mentioned areas. It can be argued that improvement of air quality, the quality of the urban environment, and energy security constitute the major priorities within the investigated municipalities. Thus, in this regard, the Polish municipalities have a similar priority for collecting and producing environemntal information as the Swedish municipalities.

The studied municipalities also organise local meetings with the participation of mayors, citizens, NGOs, and other organisations that act as external stakeholders 
in the municipality. Such meetings are organised in all of the city's districts. The local authorities also meet:

... the representatives of chambers of commerce, representatives of business organisations, students, researchers, mass media, all who care about the local development. Sometimes it is we [the municipality] who organise such meetings, and sometimes it is the citizens who engage themselves in finding the solution to a problem. They seek contact with us themselves. They organise themselves into a bigger group (Interview 1, the $\mathrm{EV}$ ).

The municipalities use the municipal councillors, the Councils of Housing Settlements, the Councils of Teachers, the Councils of Parents, the Investors, the Municipal Urban Office, the Urban Council, etc., to collect additional information from as wide a group of external stakeholders as possible about what has to be done in the city and its districts.

The municipal governments, similarly to what was seen in Sweden, have an interest in receiving feedback from stakeholders on the published reports, strategic plans, and programmes for environmental protection. Residents and other stakeholders can participate in e-consultations or make their voices heard at a Contact Centre, Green Line, Clean City and Purity and Ecology websites, Facebook etc., and these websites are usually divided by branches or topics. Thus, civil servants of the studied municipalities also have contact with stakeholders via the Internet, or the municipal offices' websites, Facebook, which allows collecting information from the inhabitants and other stockholders. One of the interviewees explained:

We use, among other things, the questionnaires concerning the standard of living, in which the residents provide their points of view on the shaping of public spaces. We collect their requests and comments. ... We are the first municipality in Poland that has created a plan for sustainable public transport within the framework of a revitalisation process. About 2,000 residents participated in a survey, which we perceive as a social consultation with local society (Interview 1, the $\mathrm{EV}$ ).

Summing up, the investigated municipalities from both countries collect and produce many kinds of environmental information, and this work is perceived as mandatory. Municipal governments in both countries use formal meetings and less formal communication by the Internet or social media to reach as many stakeholders as possible in order to collect and produce environmental information like annual reports, strategy documents, and plans for environmental sustainable development etc., but also to get a response on environmental reporting. In both our cases the respondents ensure that particularly well-functioning municipalities are seen as a model for imitation and even rewarded, as is the case in Sweden or seen as "good practice" in Poland. It seems that the big cities independently of the somewhat dif- 
ferent administrative division of countries, take a lead in practical work with the collection and production of environmental information.

\subsection{At what stakeholders is the environmental information targeted?}

\section{The municipalities from the Västra Götaland Region}

From the collected documents and from the interviews it is clear that two groups of stakeholders can be easily identified, i.e. the internal and the external stakeholders. The municipal government is considered to be an internal stakeholder group, while citizens and other organisations like the industry, NGOs, council associations, or the EU are perceived as external stakeholder groups. Regarding the question at whom environmental information is targeted, the respondents emphasised that "local citizens" are the most important stakeholders. The annual report on sustainable development, strategy reports on environmental sustainability, action plans or reports from specific environmental project usually pay attention to a very specific context of each municipality, and they are designed in such a way that they meet most needs of many stakeholders. One of the respondents explained this as follows:

Our council has signed the Covenant of Mayors [launched by the European Commission to endorse local authorities in the implementation of sustainable energy policies, authors' comment]. The prime stakeholder then, of course, is the Covenant of Mayors Office, and we must produce information that is concurrent with the guidelines in order to gain support and to be able to offer good examples to other municipalities in the EU. But when we complete our reports, we also try to make them interesting to our citizens, and we publish the reports on our website (Interview 2, the VGR).

According to the respondents from all the investigated municipalities, the external stakeholders to whom the environmental information is addressed constitute other organisations in the municipality, such as local businesses, associations, NGOs, other municipalities, and the European Union. Moreover, the municipal offices of the Västra Götaland Region usually have significant numbers of contacts with researchers, students, and journalists who seek information on specific environmental matters. All reports dealing with environmental issues can be found on the municipal offices' websites, and everyone can download them. However, none of those interviewed has monitored how frequently such reports have been downloaded.

Data on energy use, air quality, and noise are reported to the internal and external stakeholders. Even though most of such information is disseminated voluntary, it is important according to the respondents because the dissemination of environmental information serves as a benchmark for comparisons. Such data should 
be and is presented on various websites, e.g. Environmental Barometer, Sweden AB (Miljöbarometern, Sverige AB), where the Swedish environmental performance is presented. The presentation of such information shows to others that the municipal government is a modern and successful public administration. One of the interviewees explained:

\section{A progressive local government must have a good environmental record. And we have to show it by comparing ourselves to other local governments. We compete with other local governments for environmental awards every year, and thus, of course, it is im- portant to display your goals, key indicators, and actions taken (Interview 1, the VGR).}

It should be emphasised that in Sweden, according to the Fundamental Law on Freedom of Expression, SFS 1949:105, every document produced in or received by the local government must be available to everyone. This regulation makes it possible for the citizens and other stakeholders to become well informed about the activities of the public sector.

Although the respondents have underlined the importance of external stakeholders as the target group for environmental information, the interviews also indicated the significance of internal stakeholders. However, internal respondents seems to be taken for granted. The municipal government needs such information in the daily operations. The respondents shared the opinion that the environmental information is being used when the municipal authorities make decisions about, e.g. construction, public procurement, waste management etc., but that goes without saying.

\section{The municipalities from the Łódz Voivodship}

Similarly to Sweden, the stakeholders of the Polish municipality are also divided into internal and external stakeholders. The internal stakeholders include staff of departments and units belonging to the organisational structure of municipal government. The external stakeholders are the city inhabitants and other organisations, such as the state central authorities, the voivodship authorities, industry organisations, investors, NGOs, local associations, mass media, neighbouring municipalities, twin cities from Europe, and the EU. On the question of what groups among the stakeholders are most important to the municipal government, all of the respondents agreed that it is the local residents, investors, and NGOs as well as researchers and the mass media. One of the respondents explained:

The most important are the residents along with the investments and the investors, those who are directly associated with any single project. We tend, however, to keep contacts with the nongovernmental organisations and with the district councils. Academics are necessary, too, because they provide us with opinions 
and expertise. We also have close relations with the services responsible for spatial planning, for example the Municipal Urban Office and the Urban Council (Interview 2, the $Ł R$ ).

Another respondent added:

Municipal residents and business people are the most important stakeholders, while the municipal workers are the 'minor' stakeholders because they constitute part of the public administration, and they participate in planning and management (Interview 3, the $€ R$ ).

The environmental information addresses both internal and external stakeholders. A mandatory obligation is to disseminate this information among the internal stakeholders, i.e. the city halls, their various units, and the offices that provide important services to the public sector, e.g. the Municipal Sewage Office, the Office of Municipal Waste, the Office of Planning and Urban Development, the Investment and Renovation Office, and the Workshop of City Planning as well as units that the city depends upon, e.g. the City Road Management and Maintenance. One respondent explained: "We collect this information for us, to see how we perform our duties" (Interview 2, the $€ V$ ). In the same spirit, another respondent said:

We also gather the reports from the Department of Municipal Economy (Wydzial Gospodarki Komunalnej), which contain important information for us to balance energy costs and its use. With this information, we build the development strategy for the city. The strategy is always developed in consultation with many stakeholders (Interview 1, the $\mathrm{EV}$ ).

The mandatory information addressed to external stakeholders is regulated by national legislation and by local regulations, which are usually in line with the EUROSTAT standards. One respondent explained that it is a question of the necessary data collection for the Central Statistical Office in Warsaw and for the local statistical offices:

We have a systematic cooperation with the Statistical Office, and we collect data for them. We collect information from the Environmental Protection Agency and from the citizens who expect interventions from us. For example, the residents see that trees are being cut and they do not agree with that, they see illegal garbage dumps and they do not want to have them in their environment, or they see smoke coming out of chimneys and they demand that the bio-patrols punish those who incinerate prohibited things (Interview 1, the $€ V$ ).

The municipal offices collect information about sewage sludge from industrial and municipal wastewater treatment plants; industrial and municipal wastewater 
discharged into waters or into the ground; the quality of water from waterworks supplied to the population for consumption; wastewater discharged by sewage networks; wastewater treatment plants; total emissions of sulphur dioxide, nitrogen oxides, and particulates by sources of pollution; greenhouse gas emissions; emission and reduction of air pollutants; protected forests or areas of special natural value; etc. All of these collected data allow for comparisons across the country and between the European states. The respondent from Municipality 2 explained:

We face the legal requirements for the protection of the natural environment. Some organisations have to provide the reports on municipal waste. Those who possess their own water or septic tank, e.g. industrial plants and sewage treatment plants, need to inform us about their pollutants. We have a duty to control them in order to produce our annual reports that we transfer to the Marshal Office, the Voivodship Office, and the Statistical Office (Interview 2, the $€ V$ ).

However, when asking the question to whom environmental information is addressed, all respondents answered similarly that it was first of all "the local residents". Some respondents added "... but also the business organisations and NGOs" (Interviews 2 and 3, the $\mathrm{EV}$ ) or "local associations, local newspapers, local TV, mass media, etc." (Interview 1 and 4, the $\mathrm{EV}$ ). One of the respondents said:

We obtain financial resources from the Voivodship Office, for example to improve the quality of sanitary connections and to exchange coal stoves for more ecological stoves that perform lowemission combustion. We want to protect the environment, and we ask the local society for its assistance in promoting such activities in our municipality. Our information is available on the municipal office's homepage, and the civil servants make contact with local TV or local newspapers to ask about ways to transmit our information to the public. Willing people or organisations are also seeking us on their own, and they organise the educational courses addressed to various target groups. NGOs help us, and they are leading environmental educational campaigns while we finance their educational programmes (Interviews 2, the $\mathrm{tV}$ ).

The Report on the State of the City, which we have produced since 1998, contains all the information that the people need. There are students, scientists, journalists, and entrepreneurs who want to enter the market, and they all benefit from this information. The report is on our website, and we see how many people are viewing it. Sometimes people ask questions, so each year we can enrich our information on sustainability in the report (Interviews 3, the $E V)$. 
The interviewed have emphasised that in Poland there is still a lot of work to be done to protect the natural environment. Hence, the dissemination of environmental information has to be adapted to the local context, economic conditions, and current needs in order to really make improvements. We have the impression that the municipal authorities from the Łódz Voivodship go beyond their legislative obligations to protect the natural environment, and the municipal governments appear to give great priority to environmental education, which is present and visible almost everywhere within the investigated Polish municipalities. The municipal authorities probably believe that such education, which starts in kindergarten, and which can be visible on streets or in shops, can contribute significantly to making the various stakeholders much more sensitive and willing to protect the natural environment.

Summing up, comparing at what stakeholders the environmental information is targeted, the findings are similar in the two cases. In both countries, the respondents have mentioned first the citizens, and secondly, other external stakeholders as the most important stakeholders. Citizens because probably the municipal governments want to show their accountability towards inhabitants, other external stakeholders, such as statistical offices, various national, regional/voivodship's authorities responsible for the protection of the natural environment, because it is mandatory to keep them updated in order to improve strategies and policy documents or even reporting on environmental sustainability. The Swedes are talking about a benchmark for comparisons among the municipalities. The Poles are talking about the measuring of progress in the protection of the natural environment, comparisons across the country and between the European states, which is another expression for benchmarking. We have the impression that in Sweden, the dissemination of environmental information among various stakeholders is more anchored in the residents' will and awareness that anyone can contribute to the protection of the natural environment, while in Poland, the dissemination of environmental information also goes beyond the mandatory obligations but for an educational purpose to create and develop such awareness among its citizens as we could observe in the municipalities from the VGR.

\subsection{The impact of the information on stakeholders' decision-making}

\section{The municipalities from the Region Västra Götaland}

The respondents' knowledge of the use of environmental information disseminated by the municipal offices varies, depending on the type of stakeholder being discussed. They say they have a good overview of the use of environmental information in decision-making by the internal stakeholders, while they are lacking systems for knowing what the external stakeholders do with such information and how it influences their decision-making. According to the respondents the municipal offices collect, produce, and disseminate environmental information in line with 
different stakeholders' needs and demand. Thus, when analysing the documents, listening to interview records and when reading the interview transcripts, we have identified stakeholders and the various kinds of justification the respondents ascribed to the dissemination of environmental information. When talking about the internal stakeholders belonging to the organisational structure of the municipal government, the respondents emphasised that the dissemination of environmental information is not only mandatory but also necessary for the civil servants. They need the information to be able to prepare political decisions, estimate progress towards the major objectives, report back comments on development, etc. The dissemination of environemental information has become a necessary basis for decision-making in a multitude of areas, not only in environmental development by the municipal authority.

The environmental information addressed to the external stakeholders is justified in many ways, e.g. as the need for the local government to show accountability towards its inhabitants. Other organisations in the municipality, e.g. in the business sector, receive the environmental information, either to support them in their adaptation to the municipal conditions or to influence their activities and make them environmentally friendly. Regarding other municipalities or local-government associations, the justification is mostly related to benchmarking and comparisons. The central governmental authorities such as the Swedish Environmental Protection Agency and the Swedish Energy Agency receive the environmental information since they are inspecting authorities of such municipal activities. The dissemination of such information to the EU serves for international comparison, eventually for endorsement and support. However, the interviewees admit that it is very difficult to estimate if the published reports about environmental issues meet the needs of the stakeholders. Regarding the external stakeholders, the most frequent opinion is:

People request a lot of information, but often they request something very specific. For example, sometimes they ask for something that we do not measure in that particular way but in another way, such as driving distance or carbon-dioxide emissions or energy usage (Interview 4, the VGR).

Another respondent added that the municipal inhabitants and other stakeholders require information on specific projects like, for example, the municipal project dealing with the public procurement of more ecologically produced food for the local schools and nursing homes. The EU, central-government authorities, and local-government associations often request environmental information that is specific to their needs. It is at that point of the project where financial information (such as the project's estimated cost of different levels of ambition) is important, but also other measurements. One of the interviewees suggested:

The financial information is important to the project as a whole. But the expectations for me are, for example, to remove a cer- 
tain amount of lead and mercury from the soil (Interview 3, the VGR).

There is, however, a lack of a specific system by which the local councils can estimate what kind of information the stakeholders demand from the municipalities. Such information is almost completely based on ad-hoc questions from the stakeholders. But according to our respondents municipal environmental reports are valuable in displaying the importance of environmental work. The many reports, and the rich and energetic dissemination of environmental information by the municipalities, make the environmental issues impossible to ignore. And it highlights everyone's responsibility to participate in improving the situation.

According to the respondents, all of the investigated municipalities provide energy consultation to individuals, small and medium-sized businesses, and other organisations. This counselling service is perceived by the respondents as popular and as having a positive impact on sustainability. At the same time, the respondents also admitted that they have limited knowledge of whether published reports or disseminated environmental information have had any influence on decision-making by citizens, business organisations or other stakeholders. Thus, the respondents' knowledge about the use of environmental information by external stakeholders is totally different in comparison to their knowledge about the use of environmental information by internal stakeholders.

The official documents and the interviews show that the environmental information collected, produced, and disseminated by the investigated municipalities in the Västra Götaland Region in general is very important for decision-making by the municipal politicians. A report on the natural environment is mandatory since the EU requires that local authorities produce a strategic environmental assessment, plan, or programme, having a positive impact on sustainable development (see SEA Directive 2001/42/EC). However, the respondents reported that the municipal governments and the municipal politicians discuss their local development whether it be mandatory or not.

In 1999, the Swedish Parliament made a decision about the national environmental objectives for the country. Those major objectives have been widely promoted by the state authorities, and they have been translated into operative goals by public organisations, companies, and other organisations. However, it is still unknown to what extent the sustainability reports have had an impact on decisionmaking within the Swedish municipalities. Perhaps it is a question of political will or party affiliation. It should be added that in Sweden the party line is very strong; the local council politicians tend to vote according to their party's policy in every respect, and thus they also vote in a similar way regarding sustainability matters.

All of the respondents emphasised that the municipalities offices have often needed comprehensive environmental information in order to make decisions, e.g. when organising public procurement, town planning, or waste management or 
when making decisions on local transportation. Such reports and documents have not been available on the municipal offices' websites; instead, everyone has access to the council boards and committees' proceedings, which is in line with the Fundamental Law on Freedom of Expression, SFS 1949:105. Thus, the citizens can track and download every regulation or document dealing with environmental information that was a basis for decision-making by the municipal authorities.

Information from the stakeholders directed to the municipal authorities can potentially support the municipal politicians' decision-making on various environmental initiatives. However, the respondents explained that the civil servants from the municipal offices have to apply for resources in order to start an environmentally friendly project or programme. Shortly after applying, the civil servants are informed whether they will or will not receive the funds for the sustainability work. Reporting about spending money and the effects of the project or programme are the main requirements for receiving funding, and civil servants are usually well informed about how to meet those requirements in the best way.

\section{The municipalities from the Eódz Voivodship}

The Polish respondents emphasised that in general, the everyday work within the municipal offices is based on the dissemination of every kind of information among the internal stakeholders, thus the environmental one, too. Such information is seen as necessary to fulfil the municipal goals, to plan potential projects or programmes for environmental improvement and to make decisions about the future municipal development. But similarly to Sweden, the respondents do not have knowledge of the external stakeholders' use of environmental information and if such information has influenced their decisions. The justification behind the dissemination of environmental information among stakeholders within the investigated municipalities seems to have first of all a mandatory character. The collection, production, and dissemination of such information is seen as "a must". Secondly, we have found arguments similar to those that the Swedish respondents expressed, e.g. the municipal offices disseminate the environmental information to business organisations to support them or make their activities environmentally friendly; such information is necessary to make comparisons possible among municipalities in a voivodship, country, or internationally. The central and voivodship authorities, such as, respectively, the General Director for Environmental Protection or Regional Directors of Environmental Protection, but also the Voivodship Office and the Marshal Office, receive the environmental information to supervise the municipal activities, if they run according to the national and regional objectives. Similarly to the Swedish situation, the dissemination of such information to the EU makes possible international comparisons; it eventually endorses or supports the EU member country in its sustainable development. It should be added that the Łódz Voivodship has received such support from the EU, which is influencing the investigated municipalities' practical work with environmental sustainability. 
Sustainable development in Poland is perceived as a link between rapid economic development and a higher standard of living. The natural environment as measured by objective indicators shows the improvement of people's quality of life. Poland follows Directive 2001/42/EC, just as Sweden does. However, before the EU Directive of 2001, the Polish Parliament passed a resolution on 2 March 1999, that obliged the Council of Ministers to elaborate upon "Poland's Sustainable Development Strategy until 2025" (Monitor Polski: Dziennik Ustaw 1999, 96), and the Government was expected to submit a relevant document by 30 June 1999. In 2003, the Council of Ministers adopted an important document - Poland's Climate Policy: The Strategy for Reduction of Greenhouse Gas Emission in Poland until 2020 - which was prepared by the Ministry for the Environment. This document describes (1) basic problems and conditions of Polish climate policy, (2) major objectives and priorities of Polish climate policy, (3) actions and performance by different sectors until 2020, (4) strategic methods for the reduction of greenhouse gas emissions, (5) recommendations for Polish climate policy, (6) the role of NGOs, and (7) the costs and benefits of different sources of financing (Politika klimatyczna Polski 2003). After nine years' negotiations, the first regulation, i.e. The State Environmental Policy for the Years 2009-2012 with a Perspective for 2016, and with the necessary amendments was in force in 2008 (Dziennik Ustaw 2008). Poland has relatively quickly begun to make up for lost ground:

This difficult task was supported financially by the EU funds, first under the ISPA programme, then by the Cohesion Fund, within the framework of the 2004-2006 Cohesion Fund for Strategy and the European Regional Development Fund as part of the Integrated Regional Operational Program and the Sectoral Operational Program for Improvement of the Competitiveness Companies as well as the European Agricultural Guidance and Guarantee Fund for the Rural Development Plan 2004-2006 and the Sectoral Operational Program 'Restructuring and Modernization of the Food Sector and Rural Development 2004-2006'. Since 2004, environmental projects could also receive funding from the European Economic Area Financial Mechanism and the Norwegian Financial Mechanism (Polityka ekologiczna państwa... 2008, 5).

As a consequence of this document, the total donation for Poland's sustainable development was about $€ 6.3$ billion, which did not cover more than $20 \%$ of Poland's necessary expenditures on environmental investments in 2007-2013. The remaining $80 \%$ of the funds had to be allocated by the Polish side. The State Environmental Policy was in line with the EU's major priorities, advocating for (1) actions to ensure the implementation of the principle of sustainable development, (2) adaptation to climate change, and (3) the protection of biodiversity. Since 2008, we can talk about the state's systematic work with sustainable development in Poland. It should be added that on 17 November 2008, a new government organ was estab- 
lished - the General Director for Environmental Protection and Regional Directors of Environmental Protection - which represented the central and voivodship governmental administrations. The new organ was to deal with specialised environmental protection services like environmental impact assessments, nature management including the European Nature Network 2000 - and issues regarding competence in environmental responsibility. The expectation was that this new institution would significantly simplify and speed up the environmental procedures (Polityka ekologiczna państwa... 2008, 8). However, those facts suggest that the Polish municipalities where working under pressure from the external stakeholders, controlling local developments conducted by municipal governments.

Looking for empirical evidence from the key managers of municipal offices, they mentioned innovative work with the local inhabitants. For example, some years ago a new initiative was started that was referred to as the civil budget, which is now in its fourth version in some of the municipalities within the Łódz Voivodship. Looking at the homepages of the investigated municipalities, this institution is visible everywhere, but it does not have a compulsory character in Poland. The concept was introduced first in 2011, and in 2014 only 30 Polish cities had introduced civil budgets. The civil budget is a separate part of the municipal budget. Citizens can submit proposals for annual tasks, and these can be included in the municipal budget. Such proposals inform the municipal authorities about what activities should be given priority. Citizens can also vote on budget items and by that can influence the decision-making process. Respondent 2 explained:

\section{They [the voting citizens] are visible on social media, and we have well-developed homepages that are informative about all of the important issues for the city and its inhabitants. The voting occurs through our website (Interview 2, the $\mathrm{EV}$ ).}

However, according to the Facebook page from Municipality 1, too few people vote. Moreover, the local inhabitants can manipulate the vote: "Again, there are ideas that the procedure of the civil budget should be changed to make it even more restrictive. So far, though, nothing has come of it. The city's residents always find a way to bypass the rules and 'play for themselves"' (Facebook, Municipality 1, 12 November 2016). Thus, the participation of citizens is a disputable issue and has something in common with the experiences from the municipalities within the Region Västra Götaland, where the municipal authority involves many more experts and technocrats in the municipal work than local residents.

Similarly to the Swedish municipalities, it is difficult in the municipalities from the Łódz Voivodship to estimate what environmental information the stakeholders require. The municipal offices are obligated to provide information if anyone asks a question about environmental sustainability. The respondents reported that stakeholders often ask about very different and rather concrete issues, for example: 
When will the replacement of the coal stoves with the low-emission stoves take place in the municipality, when will the illegal garbage dump be removed, or what is happening with the felling of trees? (Interview 4, the $\mathrm{EV}$ ).

Another respondent said: "Nowadays, people watch each tree" (Interview 3, the $€ V)$. According to the respondents, the stakeholders from the investigated municipalities want to participate in the local development and want to have an impact on its strategic planning and the programmes dealing with the modernisation and renovation of things like housing buildings and municipal sewers. They also want to contribute to decreasing pollution and greenhouse gas emission. All of this aims at increasing the standard of living not only in the studied municipalities but in the whole voivodship. In addition to ordinary citizens, representatives of businesses and NGOs often ask about different programmes. Thus the external stakeholders have the opportunity to participate in the municipal development and planning through the civil budget.

From the interviews, it appears that the production and dissemination of ecological information helps in the decision-making either by the municipal authorities - the internal stakeholders - or by investors, entrepreneurs, and municipal inhabitants - the external stakeholders. The respondent said:

Potential entrepreneurs receive permission from us to open a business. We provide them with information on the environmental activities before they start their business. From the beginning, they have to follow the environmental standards. It is very important for our local community (Interview 2, the $\mathrm{EV}$ ).

Other respondents explained:

... local society is aware of the environment and people want to carry out educational activities to change their habits and contribute to the increasing protection of the natural environment. To keep them going, we [the Municipal Office] organise Family Picnics, usually in May. There we give plant seedlings to people in order to get them to work pro-environmentally. It is our initiative, our decision (Interview 3, the $\mathrm{EV}$ ).

We had the idea to build a viaduct in the central part of the city, but the residents were of the opinion that we should instead allocate those resources into the development of modern rail transport to reduce carbon-dioxide emissions. We bought a lot of modern trams and buses, and in five years it will be even better (Interview 1, the $\mathrm{EV}$ ).

The last quotation suggests that the dissemination of environmental information among stakeholders and the process of social consultation are important for 
decision-making by the municipal authority but also show that social awareness about the necessity to protect the natural environment is increasing among people. The abovementioned decisions proved to be in line with the residents' expectations. However, the respondents acknowledge that their knowledge about how the dissemination of environmental information influences the decision-making of the municipal politicians and other stakeholders is rather limited, similar to the situation of the municipalities in the Västra Götaland Region. One of the respondents said: "Sustainable development requires time, preparation, commitment, and patience" (Interview 2, the $€ V$ ). Some positive, innovative trends in the working methods with the protection of natural environment are visible, but they also demand the decisions made by the municipal authorities. In Municipality 1 , for example, the municipal council has two programmes - "Clean City" and "Purity and Ecology".

Both of these programmes have their own website on which the
municipal council informs local society about important planned
initiatives or actions that have been taken. The websites also serve
as a communication channel between the municipal council and
the stakeholders (Interview 1, the $\mathrm{EV}$ ).

All of the investigated municipalities in the Łódz Voivodship cooperate with their stakeholders in similar ways. However, the size of the municipality determines the scope of the decisions, initiatives, or activities. It seems that smaller municipalities follow the pragmatic ideas of bigger cities in the voivodship or even those of their twin cities elsewhere in Europe. The cities that are successful in the protection of the natural environment have become role models - best practice - for other municipalities of the Łódz Voivodship.

Summing up, according to the key respondents from the Swedish and Polish investigated municipalities, the dissemination of environmental information has an impact on decision-making first of all by the internal stakeholders, i.e. the municipal governments responsible for municipal development in many respects, thus for the protection of natural environment, too. Their daily work requires collecting information, producing reports, sharing them with various departments responsible for environmental issues within the organisational structure of municipal government. This, in turn, serves as the basis for decision-making by the municipal authorities. The respondents from both countries have admitted that they do not know how the dissemination of such information influences the external stakeholders' decisionmaking. Neither the respondents' justification behind why the municipal offices spread the environmental information nor the respondents' description of practical work with the dissemination of such information makes us any wiser. We still do not know if the dissemination of environmental information supports the external stakeholders' decisions and to what degree it does because no municipality has developed the system to monitor it. Only indirectly has it been explained by the interviewees that such information is important for decision-making by stakeholders. 


\section{Discussion and conclusions}

The purpose of this research was to fill a small gap in current knowledge; to describe and compare the local governments' practical work with the dissemination of environmental information among stakeholders and to explain this information's effects on stakeholders' decision-making. The work presented here focused on municipalities in Sweden and Poland and sought to answer the following questions: (1) What environmental information is collected and produced by the local government and why? (2) At what stakeholders is the environmental information targeted? (3) What impact does such information have on stakeholders' decision-making?

When answering the research questions, we discuss the findings with theoretical insights presented in section 2 in order to draw conclusions from our investigation. However, as Burritt (2009), Gray et al. (2009) and Guthrie et al. (2010) have underlined, research on practical work with the dissemination of information on sustainable development is lacking. Only some exceptions can be found, e.g. Farneti and Guthrie (2009) or Bellringer et al. (2011), who studied how sustainability reporting was carried out, including references to any guidelines; how information was collected and reported; and who was involved. Moreover, the fact that Sweden is one of the most successful countries regarding the protection of the natural environment, while Poland is far behind and partly dependent on EU or Norwegian funding makes comparisons between the Swedish and Polish municipalities challenging but possible.

Both countries are EU member states, and they are expected to share the same values and norms regarding the protection of the natural environment. They are expected to follow the EU regulations and major objectives for sustainable development, which have been voluntarily accepted by the EU member states as Action Agenda 21. The respondents from the Polish municipalities much more frequently emphasised the importance of Directive 2001/42/EC and similar EU recommendations for practical work with the protection of the natural environment than the Swedish respondents. One explanation might be that the on-going systemic transformation in Poland since 1990 has led Poland to be much more sensitive to EU recommendations and environmental standards in order to show that the country is complying with mainstream policies, while Sweden being an example of good practice and the pattern to follow does not need to legitimise its practical work with environmental sustainability. The Swedish municipalities have a long tradition in this regard but independently of that even the successful country has had to adapt partly its collection of environmental information, production of reports, and their dissemination to the requirements of EU or EUROSTAT. All this can be seen as attempts to standardise a growing number of regulations, directives, and recommendations to influence capacity-building processes at all governance levels across Europe, the neighbouring countries and contributes to administrative convergence, as some scholars (see Olsen 2003; Trondal and Jeppesen 2006; Hofmann 2008: 
Heidbreder 2011; Trondal and Peters 2013; Sobis and de Vries 2017) have described it in terms of the rise of the European Administrative Space. As some kind of confirmation for such standardisation serves our observation; the Swedish and Polish municipalities have a similar level of autonomy in governing, according to the state legislation. However, the municipal governments' activities are controlled in a different way. The last issue is beyond our interest in this article.

What environmental information is collected and produced by the local government and why? Our study indicates that both countries have developed a national strategy and formulated major objectives for sustainable development. These documents have become the guiding principles for practical work at the local level. The major national objectives have been translated into local strategies paying attention to local contexts. Thus, our study confirms the earlier observations of Williams et al. (2011), who ascribed to local governments decisive importance for practical work with sustainable development, where the protection of natural environment constitutes the integral part. In both countries the civil servants from the investigated municipal offices collected data on environmental sustainability, produced reports and presented environmental information, as expected by EUROSTAT. Lodhia et al. (2012) also confirm this practice that legislative and administrative policy documents have a significant impact on practical work with the collection, production, and dissemination of ecological information among stakeholders at the local level. The Swedish and Polish respondents referred to the national regulations that obligated the investigated municipalities to collect environmental information, produce reports on environmental sustainability and make most of such information accessible to everyone, which again was regulated by law in both countries. It can be partly explained by Larrinaga-Gonzalez and Bebbington's theory (2001) dealing with the array of political, functional and social pressure. Many advocate for the fact that the investigated Swedish and Polish municipalities have been under such pressure, but in contradiction to Larrinaga-Gonzalez and Bebbington's opinion, it seems that such pressure has had some positive effects for the protection of the natural environment in both countries, which confirms statistical data from Sweden and Poland. This study shows that since 2014 Swedish local governments have been obligated to produce reports on energy consumption and environmental protection costs to Statistics Sweden. Looking into the Swedish Statistical Yearbooks, information on environmental protection follows the EUROSTAT standards, but it is lacking the regional and municipal statistical yearbooks. Of course, such information for each municipality is available from the homepages of the Region Västra Götaland, its County Administrative Board, or the Swedish Environmental Protection Agency (Naturvårdsverket), but it is difficult to find detailed information for the whole region in one report. Instead, it is possible to buy such data from either the mentioned agencies or from Statistics Sweden, which is profit-oriented. Other mandatory reports concern the environmental impacts of urban and rural planning. According to the respondents from the Swedish municipalities, they have also 
produced other reports on sustainability, such as annual reports, environmental sustainability strategy reports, reports on sustainable transport, environmental risk analyses, environmental footprint reports, climate plans, etc., which are not mandatory and are produced voluntarily. Moreover, the best annual reports are rewarded by research associations or by auditing organisations, which stimulates other local councils to further develop their efforts in this regard. In Poland, the collection and production of environmental information, such as strategy reports, development programmes, environmental-protection programmes, and annual reports for the Marshal Office, the Voivodship Office, and the Regional-, and Municipal Statistical Office have been mandatory to Polish local governments. The presentations of data on environmental sustainability in the reports addressed to the Voivodship and Municipal Statistical Office are in line with the EUROSTAT standards, too. The comparisons on a regional or local level in Poland are much easier to conduct than in Sweden and without extra payment. Thus, the record of environmental reports and other documents dealing with the production of ecological information differs in the two countries. One gets the impression that the Polish municipalities produce much more information on environmental sustainability than the Swedish municipalities. A possible interpretation is that the Polish municipalities are still beginners in the sustainability business, and they need to show more action in order to be seen as legitimate in their practical work with sustainable development. By mentioning many reports and strategic plans, the respondents from the Polish municipal governments tried to ensure accountability. When comparing the actual amount of information in the homepages it is also evident that the Swedish municipalities have more than what is stated in the interviews. Another interpretation could be that the longer list of reports on the homepages of Polish municipal offices is somewhat deceptive because in Sweden much more sustainability information is presented on the homepages of the Region Västra Götaland, its County Administrative Board, and the Swedish Environmental Protection Agency than on the homepages of the Swedish municipal offices. In any case, in both countries everyone can find enormous amounts of regulations, strategies for sustainable development, annual reports, environmental programmes, documents, information for investors and inhabitants, brochures, statistics, etc.

At what stakeholders is such information targeted? We could see in the previous section that in Sweden, the Fundamental Law on Freedom of Expression, SFS 1949:105 and in Poland the Act of 6 September 2001 on access to public information urge the introduction of information bulletins for the public, constitute the regulations that obligate the municipal governments in both countries to publish, and thus disseminate to the public, state regulations, local policy documents, every signed political decision, annual reports, strategic documents for municipal development, proclamations, etc., all in the name of transparency of public-sector activities. These regulations stimulate practical work with the dissemination of environmental information among stakeholders. However, data must first be collected 
from relevant stakeholders, e.g. from the public and private sectors, and from business organisations as well as from individual citizens, and this is a precondition for the practical work with the production of environmental information that later on can be disseminated among various stakeholders. The production of environmental information in both countries is addressed to both the internal stakeholders and the external stakeholders. However, when asking who is perceived to be the most important stakeholder? the respondents from both countries answered quite spontaneously, "the citizens." This answer runs contrary to the findings of Farneti and Guthrie (2009) and Bellringer et al. (2011), who state that the most important stakeholders are the internal stakeholders in the public sector (see also Burritt and Schaltegger 2010). However, when analysing in depth the respondents' answers to this question, it proved that it is so obviously taken for granted that first the internal stakeholders need the environmental information that the respondents did not think about them in the first place. Maybe, we have witnessed what Crespy and Miller (2011) also discuss, we might have to shift our understanding of the concept of stakeholder. Currently, the most important stakeholders seem to be those who are affected by a stake, not those who have a stake. In both countries the respondents have also mentioned other external stakeholders, such as investors, NGOs, mass-media, and the like. We would also like to point out that when comparing the respondents' knowledge on the actual use of environmental information it is evident that the interviewees have been very well aware of the importance of environmental information in decision-making processes within the municipal governments. Friedman and Miles (2006), but also Rixon (2010), share the opinion that if public organisations want to be seen as accountable for local development the consultation with various external stakeholders should go beyond the dissemination of information. Our study shows that the citizens or other external stakeholders' participation in the consultation occurs in a more outspoken manner within the Polish municipalities, and it is perceived as innovative work. This might be a consequence of the long-lasting trend within the EU, as Kamlage and Nanz (2017) noted that local authorities should advocate for the growing participation of citizens in decision-making. Hence, we also refer to Adolfsson Jörby (2002), with confirmation for our findings. She investigated Swedish municipalities and found that both internal and external stakeholders were increasingly important for the collection, production, and dissemination of environmental information.

What impact does such information have on stakeholders' decision-making? Our study has shown that the homepages of the municipal offices in both countries, as well as specially created websites like Green-lines, Clean City, and Purity and Ecology or presences on Facebook, have served as communication options between the local governments and external stakeholders. This observation partly confirms Larrinaga-Gonzalez and Perez-Chamorro's (2008) opinion that public organisations are engaged both formally and informally in reporting on the results of sustainability work. The respondents, especially those from the Pol- 
ish municipalities, emphasised that electronic methods of communication have essentially contributed to the improvement of annual reports on environmental sustainability as well as to the improvement of organisational strategies and operational activities to advance the work with the natural environment. Thus, the participation of citizens and their influence on environmental sustainability proved important for the municipal authorities. However, our findings indicate support for the conclusions drawn by Feichtinger and Pregernig (2005), who state that in Sweden experts and technocrats are the driving force behind decisions made by the local authorities, not local citizens.

The Swedish and Polish respondents shared a similar opinion that the widely understood information on sustainability practices has positive effects on decision-making by the municipal politicians in both countries. Such information was known to be of great importance for the internal stakeholders, i.e. the municipal offices and their civil servants from various departments, which also confirms Farneti and Guthrie's (2009) conclusions. Thanks to the dissemination of environmental information among the internal stakeholders, they could learn about their own progress in their everyday environmental work. In Sweden, the internal stakeholders could identify which projects or programmes were successful and deserved to be continued. In Poland, information on environmental protection was useful for identifying local needs and for improving the situation at hand, and similarly to Sweden, the Polish civil servants could learn about their own progress in their everyday environmental work. There is no doubt that both countries are working actively with the protection of the natural environment, and such developments are confirmed by statistical data from EUROSTAT and from national yearbooks. Nevertheless, it is obvious that Poland has much more work to do to decrease pollution and greenhouse-gas emissions compared to Sweden. Polish economic development is still based on mining, metallurgy, and chemicals, and these industries constitute serious obstacles in this regard.

In both countries, it is difficult to estimate the effects the dissemination of environmental information among external stakeholders has had on their decisionmaking because systems for the municipal offices to collect such data are still lacking. Hence, we do not know how the external stakeholders use such information in practice and if it influences their decisions. This is something we find interesting and in line with Crespy and Miller's (2011) approach, who suggest that local authorities should ask the external stakeholders what effects the dissemination of environmental information among the external stakeholders has had on their decision-making to protect the natural environment. This is an important issue and a common responsibility. We have found that both countries have many positive experiences with the mandatory production and dissemination of environmental information among stakeholders, but it is especially noteworthy to emphasise that both countries lack an efficient system for data collection about how such information is used in practice by the external stakeholders and what effects it has on the 
local protection of the natural environment. We know from Ball's research (2005) that the dissemination of sustainability information might help to promote sustainability development and influence decision-making at all levels of public administration. We believe from our investigation that it is also the case with the dissemination of environmental information in Sweden and Poland. We agree with Greco et al. (2015), who highlight that sustainability information is important in political negotiations, both internally and externally, but the importance of the dissemination of sustainability information should not be taken for granted, at least not because of its "usefulness".

In conclusion, the findings from our research indicate that the dissemination of environmental information among various stakeholders has strengthened sustainability work in general. It can be seen as the forced process by the EU and Action Agenda 21 signed by the member states. It can also be seen as one of the first steps to contribute to creating the administrative convergence - the European Administrative Space at least with regard to environmental sustainability. In this respect, the large municipalities can be perceived as role models for smaller municipalities and other organisations in both countries. The dissemination of environmental information in Poland is not just simple imitation of the Swedish municipal work. The Poles also take inspiration from twin cities in Europe. Thus, organisational similarities and working methods become more or less similar. In both countries, practical work with the dissemination of environmental information is in line with the EU general recommendations, national and regional regulations.

This kind of research proved to be important because it has made us aware of what factors might improve the decision-making of the local authorities, the internal stakeholders, and the various external stakeholders. We hope that our research has contributed to revealing a shortage in daily work with information on sustainability. Although the production and the dissemination of environmental information is time-consuming and not always perceived as useful in the short run, in the long run it might have surprisingly positive effects on sustainable development both locally and globally. This article was based on various policy documents from the state, region and local levels and on semi-structured interviews with the municipal key-managers responsible for the collection, production and dissemination of environmental information, and not the potential receivers of such information. Thus, it seems necessary to conduct additional research which will focus on external stakeholders. They should also be asked about what environmental information they collect and what environmental information they need to contribute to protecting the natural environment. Such research could also be very useful for local governments to improve their practical work with sustainable development. 


\section{References}

Act of 6 September 2001 on Access to Public Information Urges the Introduction of Information-Bulletins for Public. Available at http://unpan1.un.org/intradoc/groups/public/documents/unpan/unpan034035.pdf (last accessed 27 March 2017).

Adams, Carol A. and Carlos Larrinaga-Gonzalez. 2007. "Engaging with Organisations in Pursuit of Improved Sustainability Accounting and Performance." Accounting, Auditing and Accountability Journal 20(3), 333-355.

Adolfsson Jörby, Sofie. 2002. "Local Agenda 21 in Four Swedish Municipalities: A Tool towards Sustainability?" Journal of Environmental Planning and Management 45(2), 219-244.

Algehed, Jessica and Lena Eriksson. 2012. Klimatarbete $i$ Västra Götaland - Västra Götalandsregionens arbete för att bryta den Västsvenska ekonomins beroende av fossil energy. Borås: Västra Götalandregionen.

Ball, Amanda. 2005. "Environmental Accounting and Change in UK Local Government.” Accounting, Auditing \& Accountability Journal 18(3), 346-373.

Ball, Amanda and Jan Bebbington. 2008. "Editorial: Accounting and Reporting for Sustainable Development in Public Service Organizations." Public Money and Management 28(6), 323-326.

Ball, Amanda, Jane Broadbent and Tony Jarvis. 2006. "Waste Management, the Challenges of the PFI and Sustainability Reporting." Business Strategy and the Environment 15(4), 258-274.

Ball, Amanda and Stephen P. Osborne (eds). 2011. Social Accounting and Public Management: Accountability for the Public Good. London: Routledge.

Bellringer, Amber, Amanda Ball and Russell Craig. 2011. "Reasons for Sustainability Reporting by New Zealand Local Governments." Sustainability Accounting, Management and Policy Journal 2(1), 126-138.

Burritt, Roger L. and Stefan Schaltegger. 2010. "Sustainability Accounting and Reporting: Fad or Trend?" Accounting, Auditing \& Accountability Journal 23(7), 829-846.

Communication from the Commission to the Council and the European Parliament Draft Declaration on Guiding Principles for Sustainable Development. 25 May2005. Brussels: Commission of The European Communities (COM(2005) 218 final.

Crespy, Charles T. and Van V. Miller. 2011. "Sustainability Reporting: A Comparative Study of NGOs and MNCs." Corporate Social Responsibility and Environmental Management 18(5), 275-284. 
Deegan, Craig, Michaela Rankin and John Tobin. 2002. "An Examination of the Corporate Social and Environmental Disclosures of BHP from 1983-1997: A Test of Legitimacy Theory." Accounting, Auditing \& Accountability Journal 15(3), 312-343.

Directive 2001/42/EC. Available at http://eur-lex.europa.eu/legal-content/en/ ALL/?uri=CELEX:32001L0042 (last accessed 4 March 2017).

Dziennik Ustaw 2008, No. 25, item 150. Obwieszczenie Marszałka Sejmu Rzeczypospolitej Polskiej z dnia 23 stycznia 2008 r. w sprawie ogłoszenia jednolitego tekstu ustawy - Prawo ochrony środowiska. Internetowy System Aktów Prawnych. Available at http://isap.sejm.gov.pl/DetailsServlet?id=W DU20080250150 (last accessed 4 March 2017).

Dziennik: Warto wiedziec. 2011. Największe i najmniejsze polskie gminy. Available at http://wartowiedziec.pl/index.php/start/aktualnosci/5515-najwiksze-inajmniejsze-polskie-gminy (last accessed 4 March 2017).

Fakta Västra Götaland.2015. Göteborg: Västra Götalandsregionen. Available atfile:/// Users/xsobiw/Library/Mobile\%20Documents/com apple CloudDocs/Fakta_Va\%CC\%88stra\%20Go\%CC\%88taland_2015.pdf (last accessed 27 March 2017).

Farneti, F. and J. Guthrie. 2009 "Sustainability Reporting by Australian Public Sector Organisations: Why they Report." Accounting Forum 33(2), 89-98.

Feichtinger, Judith and Michael. Pregernig. 2005. "Imagined Citizens and Participation: Local Agenda 21 in Two Communities in Sweden and Austria." Local Environment 10(3), 229-242.

Freeman, Edward. 1984. Strategic Management: A Stakeholder Approach. Cambridge: University Press.

Friedman, Andrew L. and Samantha Miles. 2006. Stakeholders: Theory and Practice. Oxford: Oxford University Press.

Gray, Rob, Jesse Dillard and Crawford Spence. 2009. "Social Accounting Research as if the World Matters: An Essay in Postalgia and a New Absurdism." Public Management Review 11(5), 545-573.

Greco, Giulio, Nick Sciulli and Giuseppe D’Onza. 2015. “The Influence of Stakeholder Engagement on Sustainability Reporting: Evidence from Italian Local Councils." Public Management Review 17(4), 465-488.

GUS (Główny Urząd Statystyczny). 2016. Statistical Yearbook of Republic of Poland. Warsaw: Central Statistical Office. Available at file://Users/iwonasobis/ Downloads/rocznik_statystyczny_rzeczypospolitej_polskiej_2016.pdf (last accessed 4 March 2017). 
Guthrie, James, Amanda Ball and Federica Farneti. 2010. "Advancing Sustainable Management of Public and not for Profit Organizations." Public Management Review 12(4), 449-459.

Heidbreder, Eva G. 2011. "Structuring the European Administrative Space: Policy Instruments of Multi-Level Administration." Journal of European Public Policy 18(5), 709-727.

Hofmann, Herwig C. 2008. "Mapping the European Administrative Space." West European Politics 31(4), 662-676.

Kamlage, Jan-Hendrik and Patrizia Nanz. 2017. "Crisis and Participation in the European Union: Energy Policy as a Test Bed for a New Politics of Citizen Participation." Global Society 31(1), 65-82.

Larrinaga-Gonzalez, Carlos and Jan Bebbington. 2001. "Accounting Change or Institutional Appropriation? A Case Study of the Implementation of Environmental Accounting." Critical Perspectives on Accounting 12, 269-292.

Larrinaga-Gonzalez, Carlos and Vincente Perez-Chamorro. 2008. "Sustainability Accounting and Accountability in Public Water Companies." Public Money and Management 28(6), 337-343.

Lodhia, Sumit, Kerry Jacobs and Yoon Jin Park. 2012. "Driving Public Sector Environmental Reporting." Public Management Review 14(5), 631-647.

Manetti, Giacomo. 2011. “The Quality of Stakeholder Engagement in Sustainability Reporting: Empirical Evidence and Critical Points." Corporate Social Responsibility and Environmental Management 18(2), 110-122.

Marcuccio, Manila and Ileana Steccolini. 2005. "Social and Environmental Reporting in Local Authorities." Public Management Review 2(2), 155-176.

Mintzberg, Henry, Duru Raisinghani and Andre Theoret. 1976. "The Structure of 'Unstructured' Decision Processes." Administrative science quarterly 21(2), 246-275.

Monitor Polski: Dziennik Ustaw. 1999. Nr. 8, Marzec 11, poz. 96. Available at http:// www.monitorpolski.gov.pl/ (last accessed 26 March 2017).

Ochrona Srodowiska $w$ Wojewodztwie Łódzkim. 2014. Łódz: Urzad Statystyczny w Łódzi. Available at http://Łódz.stat.gov.pl/publikacje-i-foldery/ochronasrodowiska/ochrona-srodowiska-i-lesnictwo-w-wojewodztwie-Łódzkim-wlatach-2011-2013,1,4.html?pdf=1 (last accessed 26 March 2017).

Oliver, Christine. 1992. “The Antecedents of Deinstitutionalization." Organization Studies 13(4), 563-588.

Olsen, Johan. 2003. “Towards a European Administrative Space?” Journal of European Public Policy 10(4), 506-531. 
Politika klimatyczna Polski: Strategie redukcji emisji gazów cieplarnianych $w$ Polsce do roku 2020. 2003. Warszawa: Ministerstwo Srodowiska. Available at https:// www.mos.gov.pl/fileadmin/user_upload/srodowisko/POLITYKA_KLIMATYCZNA_POLSKI_-_Strategie_redukcji_emisji_gazow_cieplarnianych_w_ Polsce_do_roku_2020.pdf (last accessed 26 March 2017).

Polityka ekologiczna państwa w latach 2009-2012 z perspektywa do roku 2016. 2008. Warszawa: Ministerstwo Środowiska. Available at https://www.mos.gov.pl/ g2/big/2009_11/8183a2c86f4d7e2cdf8c3572bdba0bc6.pdf (last accessed 26 March 2017).

Rixon, Daphne. 2010. "Stakeholder Engagement in Public Sector Agencies: Ascending the Rungs of the Accountability Ladder." International Journal of Public Administration 33(7), 347-356.

Rocznik Statystyczny Województwa Łódzkiego [Statistical Yearbook, Łódzkie Voivodship]. 2015. Łódz: Urzad Statystyczny w Łódzi. Available at http://Łódz. stat.gov.pl/publikacje-i-foldery/roczniki-statystyczne/rocznik-statystycznywojewodztwa-Łódzkiego-2015,6,17.html (last accessed 4 March 2017).

SCB (Statistics Sweden). 2016. Statistical Yearbook. Available at http://www.scb.se/ (last accessed 4 March 2017).

SFS. 1949:105. Freedom of the Press Act [Tryckfrihetsförordningen]. Available at https://www.riksdagen.se/sv/dokument-lagar/dokument/svensk-forfattningssamling/yttrandefrihetsgrundlag-19911469_sfs-1991-1469 (last accessed 4 March 2017).

Sobis, Iwona. 2002. Employment Service in Transition: Adaptation of a Socialist Employment Agency to a Market Economy: A Case Study of Lodz, Poland 1989-1998. Göteborg Studies in Sociology 11. Ph.D. diss. Göteborg: Department of Sociology, Göteborg University.

Sobis, Iwona and Michiel S. de Vries. 2009. The Story behind Western Advice to Central Europe during its Transition Period. Bratislava: NISPAcee Press.

Sobis, Iwona and Michiel S. de Vries. 2017. "Side Effects of Standards." In Polona Kovač (ed.). Spreading Standards, Building Capacities: European Administrative Space in Progress. Bratislava: NISPAcee, 55-76.

Steccolini, Ileana. 2004. "Is the Annual Report an Accountability Medium? An Empirical Investigation into Italian Local Governments." Financial Accountability and Management 20(3), 327-350.

Trondal, Jarle and Lene Jeppesen. 2006. Images of Agency Governance in the European Union: Community Institutions, Autonomous Administrative Spaces, or Multilevel Network Administrations? Kristiansand and Grimstad: Agder University College. 
Trondal, Jarle and B. Guy Peters. 2013. “The Rise of European Administrative Space: Lessons Learned." Journal of European Public Policy 20(2), 295-307.

Wibeck, Victoria, Madelaine Johansson, Anna Larsson and Gunilla Öberg. 2006. "Communicative Aspects of Environmental Management by Objectives: Examples from the Swedish Context." Environmental Management 37(4), 461-469.

Williams, Belinda, Trevor D. Wilmhurst and Robert Clift. 2011. "Sustainability Reporting by Local Council in Australia: Current and Future Prospects." Accounting Forum 25(3), 176-186.

Wilmhurst, Trevor D. and Geoffrey R. Frost. 2000. "Corporate Environmental Reporting: A Test of Legitimacy Theory." Accounting, Auditing and Accountability Journal 3(1), 10-26. 